\title{
Pelatihan Kewirausahaan Berbasis Teknologi: Pasar Online
}

\section{Bunyamin $^{1}$, Siti Munfaqiroh ${ }^{2}$, Lailatus Sa'adah ${ }^{3}$, Rina Rahmawati ${ }^{4}$, Widanarni Pudjiastuti $^{5}$, Lindananty ${ }^{6}$, Dwi Danesti Deccasari ${ }^{7}$, Marli $^{8}$, Didik Priyo Sugiharto ${ }^{9}$, Zainul Arifin $^{10}$, Yupono Bagyo ${ }^{11}$, Wiyarni ${ }^{12}$, Eko Sudjawoto ${ }^{13}$}

\section{STIE Malangkucecwara Malang}

ila@stie-mce.ac.id

\begin{abstract}
The purpose of this activity is so that business actors have knowledge of effective online media promotion and marketing applications for increasing product sales.The problem faced by Small and Medium Enterprises (SMEs) in Mojolangu Village, Lowokwaru District, Malang City, is that they are still running their business with a traditional system. SMEs do not have adequate knowledge about online marketing and do not have adequate skills in using web-based media. The approach method is entrepreneurship training based on online market technology. The results of the development and evaluation of activities can be concluded that there is an increase in knowledge and skills in the use of web-based media with the realization of an online market as a means of promotional activities and marketing of their products.
\end{abstract}

Keywords: SME online market; Entrepreneurship training; Technology-based Entrepreneurship

\begin{abstract}
Abstrak
Tujuan kegiatan ini adalah agar pelaku usaha memiliki pengetahuan tentang aplikasi media promosi dan pemasaran online yang efektif bagi peningkatan penjualan produknya. Permasalahan yang dimiliki pelaku Usaha Kecil Mikro dan Menengah (UMKM) di Kelurahan Mojolangu Kecamatan Lowokwaru Kota Malang yaitu masih menjalankan usahanya dengan sistem tradisional, dan belum memiliki pengetahuan memadai tentang pemasaran secara online serta belum memiliki ketrampilan yang memadai dalam menggunakan media sosial berbasis web. Metode pendekatannya adalah berupa pelatihan kewirausahaan berbasis teknologi pasar online. Hasil pengembangan dan evaluasi kegiatan dapat disimpulkan bahwa terdapat peningkatan pengetahuan dan ketrampilan dalam hal pemanfaatan media berbasis web dengan terwujudnya pasar online sebagai sarana kegiatan promosi dan pemasaran produk mereka.
\end{abstract}

Kata Kunci: Pasar Online UMKM; Pelatihan Kewirausahaan; Kewirausahaan Berbasis Teknologi 


\section{PENDAHULUAN}

\section{Analisis Situasi}

Pemasaran merupakan salah satu kunci suskes dalam menjalankan usaha atau bisnis. Di jaman modern, pemasaran tidak hanya dapat dilakukan dengan cara konvensional, tetapi juga harus didukung dengan cara yang modern yaitu dengan berbasis teknologi atau IPTEK. Perubahan dan perkembangan di dunia IPTEK ini, saat ini sangat mempengaruhi segala aspek kehidupan kita. Dengan kata lain, IPTEK adalah suatu hal yang penting bagi kehidupan manusia saat ini, dan untuk masa yang akan datang.

Salah satu potensi IPTEK yang dapat dimanfaatkan adalah potensi teknologi informasi. Teknologi informasi menawarkan banyak manfaat bagi pengguna yaitu untuk meningkatkan produktivitas dan pemasarannya. Salah satu teknologi informasi yang saat ini berkembang pesat dan sangat berpotensi adalah media social. Media social memiliki potensi menghubungkan ke banyak orang dengan mudah dan gratis. Menurut Kaplan dan Haenlein (2010), media sosial adalah sekelompok aplikasi berbasiskan internet yang dibangun berdasarkan kerangka pikiran ideologi dan teknologi dari Web 2.0, dan memungkinkan terbentuknya kreasi pertukaran isi informasi dari pengguna internet. Contoh-contoh media sosial yang berkembang saat ini adalah: Twitter, Facebook, MySpace, Youtube, Instagram, Path, Whatsapp, Line, dll.

Jumlah pelaku UMKM di Indonesia tergolong sangat banyak. Meskipun masih dalam taraf mikro, kehadiran UMKM menjadi salah satu penggerak roda perekonomian secara global di Indonesia. Keterbatasan modal yang dimiliki adalah alasan kuat dari banyaknya pelaku usaha yang memulai bisnis dari kecil. Pengelolaan seadanya dan keahlian terbatas membuat laju pertumbuhan UMKM biasanya tidak terlalu cepat. Namun, ada pula yang kemudian menjadi besar dan menghasilkan profit yang lumayan. Oleh karena itu, bisnis UMKM menjadi pilihan masyarakat untuk keluar dari situasi ekonomi berat. Berbisnis juga memungkinkan pelaku usaha memiliki penghasilan baru yang bisa disisihkan untuk membeli kebutuhan keluarga dan rumah tangga. Kriteria Usaha Mikro, Kecil Dan Menengah (UMKM) menurut UU Nomor 20 Tahun 2008 digolongkan berdasarkan jumlah asset dan omset yang dimiliki oleh sebuah usaha.

Tabel 1. Kriteria UMKM

\begin{tabular}{|c|c|c|c|}
\hline No. & Usaha & Kriteria Asset & Kriteria Omset \\
\hline 1. & Mikro & Maks. 50 Juta & Maks. 300 Juta \\
\hline 2. & Kecil & > 50 Juta - 500 juta & > 300 Juta - 2,5 Miliar \\
\hline 3. & Menengah & > 500 Juta - 10 Miliar & > 2,5 Miliar - 50 Miliar \\
\hline
\end{tabular}

Sumber: Kementerian Koperasi dan Usaha Kecil dan Menengah (2020)

Dengan klasifikasi tersebut, Pemerintah berharap UMKM dapat berperan dalam membangun perekonomian nasional, termasuk pengembangan usaha berbasis potensi daerah dan berorientasi pasar. Pada ujungnya akan tercipta struktur perekonomian yang seimbang, termasuk melahirkan lapangan kerja, pemerataan pendapatan, pertumbuhan ekonomi, dan untuk mengentas kemiskinan (Nafi, 2020). Kegiatan usaha ada berbagai macamnya, diantaranya adalah usaha jasa, usaha dagang, usaha industri pengolaan, usaha pertanian, usaha peternakan, usaha perikanan, dan sebagainya. UMKM selalu punya peran dalam gerak ekonomi masyarakat. Bahkan, usaha mikro, kecil, dan menengah ini menjadi pendorong bangkitnya perekonomian setelah goncangan melanda Indonesia, seperti krisis moneter 1998 dan krisis keuangan pada 2008. Kondisi tersebut tak berlaku saat ini ketika virus corona menciptakan krisis kesehatan yang memicu resesi ekonomi (Nafi, 2020). Namun pandemi virus corona kali ini membuat banyak UMKM tak berdaya. Dengan cepat satu per satu berjatuhan. Mereka kehilangan pasar seiring melemahnya daya beli masyarakat dampak 
menurunnya aktivitas ekonomi saat pembatasan sosial berskala besar di sejumlah daerah. Di sisi lain, ketika ada permintaan akan produk, biasanya hambatan terbesar adalah pada kurangnya persediaan bahan baku (Nafi, 2020). Sasaran penerapan sistem pemasaran online pada sektor usaha kecil antara lain: memperluas potensi pasar dari produk yang jual, menciptakan sektor pasar baru yang belum pernah berhasil ditempuh dengan jalur konvensional, mengoptimalkan sumber daya yang ada dan cenderung serba terbatas, meningkatkan daya saing usaha, dan lain-lain (Ayu Puti, 2013; Triyaningsih, 2012).

Pada 2019, sekitar 185 juta orang mengakses internet di Indonesia. Angka ini diharapkan tumbuh menjadi lebih dari 256 juta pada tahun 2025 (Statista, 2019).

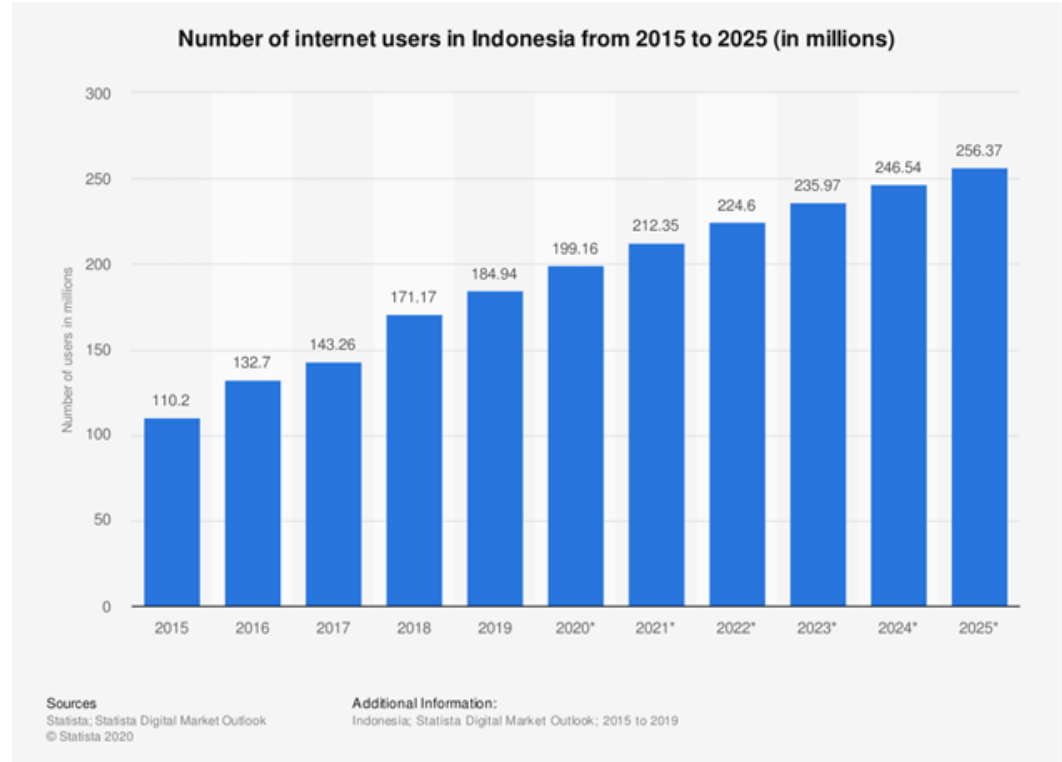

Gambar 1. Jumlah pengguna internet di Indonesia dari 2015 hingga 2025 (Statista, 2019)

Dengan lebih dari 185 juta pengguna internet, Indonesia adalah salah satu pasar online terbesar di dunia. Pada Juli 2020, penetrasi daring di negara kita mencapai lebih dari 68 persen. Aktivitas online yang populer termasuk olah-pesan seluler dan media sosial. Jejaring sosial terpopuler di Indonesia adalah Facebook dengan 82 persen populasi daring menggunakan platform tersebut. Penggunaan internet seluler sedang mengalami tingkat pertumbuhan dua digit dan saat ini mencapai lebih dari 61 persen di antara populasi (Statista, 2019).

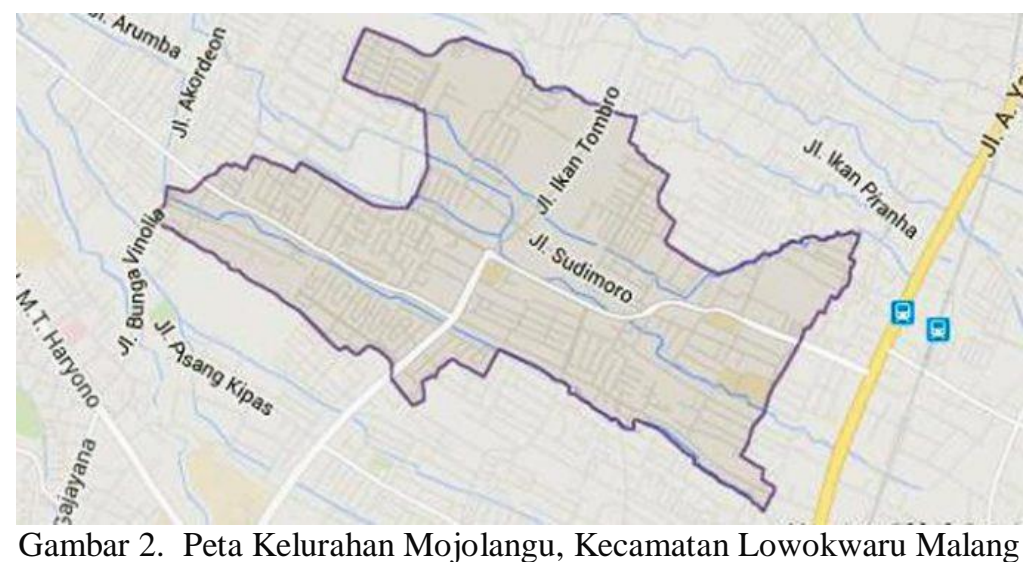

Kelurahan Mojolangu merupakan salah satu kelurahan yang berada di wilayah Kecamatan Lowokwaru Kodya Malang. Kelurahan ini terdiri dari 19 RW (rukun warga) dan 
115 RT (Rukun Tetangga), sehingga disebut-sebut sebagai kelurahan terluas di wilayah kecamatan setempat. Kelurahan Mojolangu merupakan perkampungan yang padat penduduk. Berdasarkan data dari dispenduk kota Malang, kelurahan Mojolangu memiliki wilayah seluas $2884 \mathrm{~km}^{2}$, dengan jumlah penduduk 22.905 atau 6.481 KK. Warga kelurahan Mojolangu tidak hanya terdiri dari warga asli kampung setempat, tapi juga terdapat warga pendatang yang kebanyakan mahasiswa perguruan tinggi di Malang dan juga karyawan.. Secara administratif, kelurahan Mojolangu dikelilingi oleh kelurahan lain yang ada di kota Malang. Di sebelah utara, kelurahan Mojolangu berbatasan langsung dengan Kelurahan Tunjungsekar, kecamatan Lowokwaru. Di sebelah timur kelurahan ini berbatasan langsung dengan kelurahan Purwodari dan kelurahan Blimbing, kecamatan Blimbing. Di sebelah selatan, berbatasan langsung dengan kelurahan Tulusrejo, kecamatan Lowokwaru dan di sebelah Barat berbatasan langsung dengan kelurahan Tunggulwulung, Kecamatan Lowokwaru (ngalam.co, 2015).

Pelaku UMKM di Kelurahan Mojolangu Kecamatan Lowokwaru, Malang turut terimbas pandemik sejak tahun 2020 lalu. Mereka membentuk wadah dengan anggota sebanyak 197 UMKM yang tergabung dalam pelaku pasar online kelurahan Mojolangu. Mereka dituntut mencari cara memasarkan produknya di tengah gencarnya persaingan antar sesama pelaku usaha dan turunnya daya beli masyarakat. Luasnya wilayah serta banyaknya penduduk maupun pendatang yang berdomilisi di kelurahan Mojolangu ini merupakan tantangan bagi pelaku usaha kecil untuk terlibat dan berinteraksi dengan konsumen dan pelanggan meskipun terhalang oleh peraturan dari Pemerintah. Maka tim pengabdian masyarakat STIE Malangkuçeḉwara menginisiasi kegiatan dengan tema "Pelatihan Kewirausahaan Berbasis Teknologi Pasar Online" melalui pelatihan pemasaran online bagi pelaku bisnis. Tujuan dari pelatihan ini adalah membentuk UMKM memiliki kemampuan berwirausaha yaitu memiliki pengetahuan, ketrampilan dan, sikap untuk meningkatkan pengetahuan dan keahlian, selain itu manfaat pelatihan pemasaran online, agar para UMKM dapat meningkatkan pendapatan yang akhirnya dapat mempertinggi kualitas hidupnya.

\section{Permasalahan Mitra}

Permasalahan yang dihadapi mitra adalah belum memahami cara pemasaran online untuk usahanya. Industri kecil atau industri rumah tangga di Kelurahan Mojolangu rata-rata belum paham memanfaatkan media sosial sebagai basis pasar online. Industri kecil atau industri rumah tangga di Kelurahan Mojolangu pun kurang pengetahuan untuk membangun 'brand" yang akan menciptakan penjualan. Merek dapat dibangun melalui pemasaran online (digital marketing). Pesatnya perkembangan teknologi dan dunia digital atau internet tentu juga berimbas pada dunia pemasaran. Tren pemasaran di dunia beralih dari yang semula konvensional (offline) menjadi digital (online).

Strategi pemasaran secara online ini lebih prospektif karena memungkinkan para calon pelanggan potensial untuk memperoleh segala macam informasi mengenai produk dan bertransaksi melalui internet. Digital marketing adalah kegiatan promosi dan pencarian pasar melalui media digital secara online dengan memanfaatkan berbagai sarana misalnya jejaring sosial. Dunia maya kini tak lagi hanya mampu menghubungkan orang dengan perangkat, namun juga orang dengan orang lain di seluruh penjuru dunia. Digital marketing yang biasanya terdiri dari pemasaran interaktif dan terpadu memudahkan interaksi antara produsen, perantara pasar, dan calon konsumen.

Di satu sisi, digital marketing memudahkan pebisnis memantau dan menyediakan segala kebutuhan dan keinginan calon konsumen, di sisi lain calon konsumen juga bisa mencari dan mendapatkan informasi produk hanya dengan cara menjelajah dunia maya sehingga mempermudah proses pencariannya. Pembeli kini semakin mandiri dalam membuat keputusan pembelian berdasarkan hasil pencariannya. Digital marketing dapat menjangkau 
seluruh masyarakat di mana pun mereka berada tanpa ada lagi batasan geografis ataupun waktu. Teknologi internet dapat dimanfaatkan dalam manajemen usaha kecil, baik untuk kepentingan bisnis dan kepentingan pemangku lainnya dalam memberdayakan usaha kecil, dalam bentuk portal e-marketing yang dikelola oleh instansi pemerintah dan asosiasi usaha kecil. Selanjutnya pemasaran melalui internet seperti email marketing memberikan manfaat dan kemudahan bagi para pelanggan yang menggunakan sistem belanja online dan secara positif mempengaruhi minat pelanggan online untuk memilih berbelanja pada produk yang ditawarkan (Reimers et al., 2016).

Pelatihan kewirausahaan berbasis teknologi ini berfokus pada 2 dari 8 jenis internet marketing yaitu sistem pemasaran dengan Search Engine Marketing (SEM) dan Social Media Marketing (SMM) dengan tujuan agar mitra bisa menjalankan manajemen dan teknik pemasaran berbasis internet. Pelatihan kewirausahaan berbasis teknologi dengan fokus 2 jenis sistem pemasaran tersebut didasarkan pada penelitian Yulianto (2015) yang menunjukkan bahwa kekuatan dalam pemasaran berbasis internet terletak pada website yang terklasifikasi dengan baik dan media sosial yang dijalankan.

Cukup banyak warga Kelurahan Mojolangu yang mempunyai usaha sampingan dalam bentuk UMKM (industri rumah tangga). Sejauh ini pemasarannya terbatas pada tetangga, teman maupun kerabat di sekitarnya. Meskipun telah memanfaatkan media sosial, pertumbuhan UMKM di Kelurahan Mojolangu terbilang lambat. Oleh karena itu, melalui program pendampingan dan pembinaan bagi masyarakat khususnya pelaku UMKM dan atau industri rumah tangga, maka STIE Malangkucecwara memberikan pelatihan kewirausahaan berbasis teknologi pasar online pada industri rumah tangga yang masuk wilayah Kelurahan Mojolangu tersebut. Untuk mengatasi permasalahan yang dihadapi oleh pelaku usaha kecil dan rumah tangga, maka dilaksanakan pemberian pelatihan dasar-dasar pemasaran digital sebagai tambahan wawasan para pelaku usaha tersebut dalam memandang pesaing maupun calon konsumen mereka.

\section{Alternatif Solusi}

Sesuai dengan permasalahan yang dihadapi mitra, yaitu para pelaku UMKM dan pemilik industri rumah tangga di Kelurahan Mojolangu, maka alternatif solusi yang digunakan untuk menyelesaikan permasalahan tersebut adalah dengan memberikan wawasan dan pengetahuan dasar tentang pemasaran digital sebagai basis pasar online yang akan dilaksanakan bagi semua pelaku UMKM di Kelurahan Mojolangu Kecamatan Lowokwaru, Malang dalam bentuk Pelatihan Kewirausahaan Berbasis Teknologi Pasar Online.

\section{METODE PELAKSANAAN PENGABDIAN}

Kegiatan Pengabdian Kepada Masyarakat (PKM) yang dilakukan oleh dosen-dosen STIE Malangkucecwara ini merupakan bagian tugas dari Tri Darma Perguruan Tinggi. Metode yang digunakan adalah transfer ilmu pengetahuan kepada mitra melalui pelatihan dan pendampingan. Pendampingan dan pelatihan dilakukan dimulai dengan memberikan pengetahuan dan pemahaman dasar-dasar pemasaran internet (digital) hingga mitra mampu melakukan pengelolaan pasar onlinenya secara berkelanjutan. Diharapkan mitra akan memperoleh nilai tambah dari pasar online miliknya seperti: memiliki daftar pelanggan tetap yang membeli produknya baik konsumen yang berasal dari pasar lokal, nasional maupun pasar internasional.

Kegiatan ini berupa dukungan program pembinaan dan pendampingan pasar online di Kelurahan Mojolangu Kecamatan Lowokwaru Kota Malang. Kegiatan berupa pelatihan kewirausahaan berbasis teknologi pasar online ini dilakukan secara daring melalui seminar online zoom meeting yang dilaksanakan pada hari Minggu 28 Maret 2021. Webinar online zoom meeting yang dihadiri sebanyak 34 orang yang merupakan para pelaku usaha kecil dan 
rumah tangga pasar online dan turut menghadirkan dosen-dosen dari STIE Malangkucecwara selaku pembina dan pendamping.

Adanya pandemik Covid-19 saat ini menuntut dunia untuk beradaptasi dalam menjalankan kegiatannya. Semua kegiatan pelaku usaha itu dilakukan untuk mematuhi protokol kesehatan. Demikian halnya dengan sistem pendidikan yang ada di Indonesia. Hal tersebut menyebabkan perguruan tinggi harus melakukan pembelajaran jarak jauh secara daring. Tidak terkecuali dengan kegiatan pengabdian kepada masyarakat yang wajib dilaksanakan. Dengan mempertimbangan siatuasi dan kondisi yang terjadi, maka kegiatan pengabdian masyarakat yang dilakukan oleh tim pengabdian STIE Malangkuçeḉwara dilakukan dalam bentuk tahapan atau langkah solusi atas dasar permasalahan yang dihadapi Mitra, yakni: tahap observasi, tahap konsolidasi serta tahap monitoring dan evaluasi, yang hampir semuanya juga dilakukan secara daring.

\section{Tahap Observasi}

Tahap ini diawali dengan survei ke lokasi Mitra, brainstorming dengan aparat kelurahan serta tokoh masyarakat setempat (Perwakilan RW/RT dan ibu-ibu PKK) guna menggali potensi dan permasalahan yang terjadi di kelurahan Mojolangu. Pada tahap ini berhasil diidentifikasi permasalahan Mitra, yaitu: (1) Belum dapat memahami cara pemasaran online untuk usahanya. Industri kecil atau industri rumah tangga di Kelurahan Mojolangu rata-rata belum memahami bagaimana memanfaatkan media sosial sebagai basis pasar online (2) Meskipun telah memanfaatkan media sosial, pertumbuhan UMKM di Kelurahan Mojolangu terbilang lambat.

\section{Tahap Konsolidasi}

Dalam pelaksanaan kegiatan pengabdian masyarakat ini, selain para pelaku usaha kecil dan pemilik industri rumah tangga, aparat kelurahan serta tokoh masyarakat setempat yang merupakan perwakilan RW/RT serta Ibu-ibu PKK yang ada di wilayah Kelurahan Mojolangu juga turut aktif dalam implementasinya.

Adapun luaran yang diharapkan dari program pengabdian ini adalah meningkatnya pemahaman dan wawasan pengetahuan mitra tentang pasar online dan penerapannya.

\section{Tahap Monitoring dan Evaluasi}

Monitoring dan evaluasi dilakukan dengan membandingkan aspek perilaku pelaku bisnis dalam menjalankan pasar online di wilayah kelurahan Mojolangu sebelum dan sesudah dilakukan sosialisasi untuk mengedukasi mitra terkait sistem pemasaran online yang lebih mudah dan modern.

\section{PELAKSANAAN KEGIATAN}

Kegiatan ini merupakan Program Pengabdian Masyarakat STIE Malangkucecwara yang dalam pelaksanaannya membutuhkan keterkaitan Lembaga Pengabdian Masyarakat dengan peningkatan sumber daya manusia khususnya masyarakat di sekitar wilayah Kota Malang. Sasaran pelatihan yang kami lakukan adalah masyarakat di Kelurahan Mojolangu Kecamatan Lowokwaru Kota Malang yang berprofesi sebagai pelaku UMKM. Pada pelatihan ini kami memberikan pelatihan bagi para peserta untuk mempraktekkan bagaimana memasarkan produk secara efektif dengan memanfatkan media online.

\section{Penyampaian Materi Pelatihan}

Kegiatan pengabdian ini dilakukan dengan cara:

1. Mengundang masyarakat di Kelurahan Mojolangu Kecamatan Lowokwaru Kota Malang yang berprofesi sebagai pelaku usaha sektor usaha kecil (UMKM) yang berada di bawah 
pembinaan Kelurahan Mojolangu untuk hadir secara daring dengan mengakses link undangan yang sudah disediakan (foto terlampir).

2. Memberikan penyuluhan dan pelatihan dengan menjelaskan konsep pemasaran berbasis online.

\section{Pelatihan Kewirausahaan Berbasis Teknologi: Pasar Online}

Kegiatan ini berupa pembinaan dan pendampingan pasar online di Kelurahan Mojolangu Kecamatan Lowokwaru Kota Malang. Kegiatan berupa pelatihan kewirausahaan berbasis teknologi pasar online ini dilakukan secara daring melalui seminar online lewat aplikasi Zoom yang dilaksanakan pada hari Minggu 28 Maret 2021. Seminar online Zoom ini dihadiri 34 orang, yang merupakan para pelaku usaha kecil atau industri rumah tangga pasar online dan turut menghadirkan dosen-dosen dari STIE Malangkucecwara selaku pembina dan pendamping. Kegiatan ini untuk mengedukasi mitra terkait sistem pemasaran online yang lebih mudah dan modern. Selain itu, untuk mengetahui seberapa besar pengetahuan mitra tentang penerapan teknologi dalam pemasaran dan penjualan barang. Edukasi meliputi menyebarkan informasi tentang pentingnya teknologi internet untuk mendukung bisnis atau pasar online, bagaimana mengakses teknologi internet (Search Engine Marketing website dan Social Media Marketing), juga bagaimana cara berkomunikasi dengan calon pelanggan dan cara mencari informasi melalui internet.

Pelaksanaan kegiatan diawali dengan koordinasi dengan kelompok mitra. Identifikasi untuk rancangan pasar online dan akun sosial media dari masing-masing usaha mitra. Persiapan rancangan ini diharapkan dapat mewujudkan akun media sosial yang berfungsi sebagai pasar online bagi mitra. Pelaksanaan kegiatan pendampingan dilakukan berupa pelatihan pada mitra untuk dapat mengoperasionalkan situs web serta mengoptimalkan akun-akun sosial media yang telah dimiliki. Pendampingan dan pelatihan dimulai dengan memberikan pengetahuan dan pemahaman dasar-dasar pemasaran melalui internet sampai mitra mampu mengelola pasar online-nya secara berkelanjutan dan dapat mendukung usahanya. Dalam pelaksanaan kegiatan pengabdian kepada masyarakat ini sedikit mengalami kesulitan penyampaian materi, karena para peserta memiliki latar belakang pengetahuan yang berbeda dan jenis usaha yang berbeda. Ada yang memiliki usaha toko kue kering, katering rumahan, toko kelontong, jual baju muslim online, dan lain-lain. Para peserta sangat antusias mengikuti pelatihan ini. Hal ini dapat dilihat dari pertanyaan yang diajukan oleh para peserta saat narasumber menjelaskan memberi contoh mengakses situs web dan juga cara mengoptimalkan akun sosial media yang dimiliki untuk tujuan pasar online Disamping itu respon dari para peserta pelatihan ini sangat baik dimana mereka dapat hadir tepat waktu dan mengikuti kegiatan sesuai dengan waktu yang sudah ditentukan.

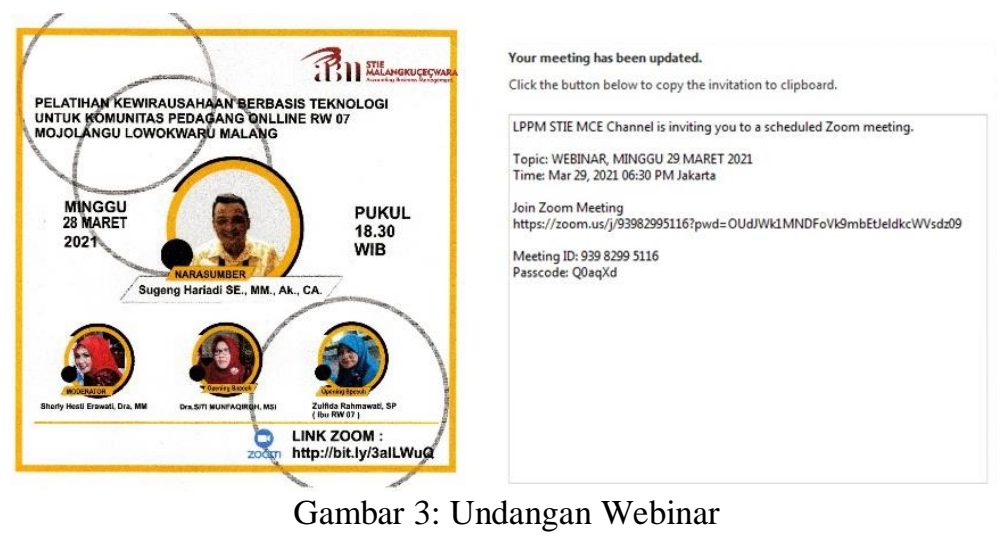



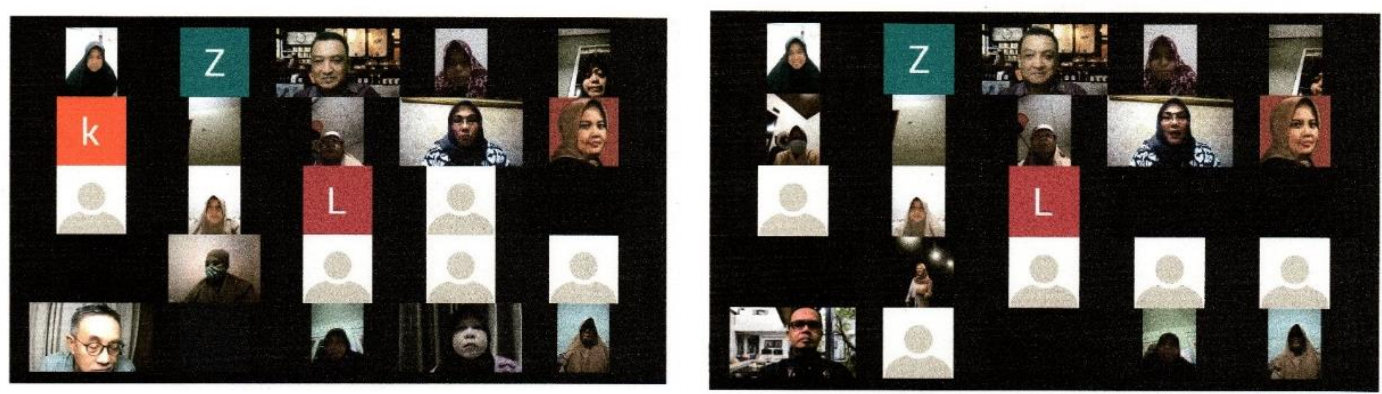

Gambar 4: Partisipan Webinar "Pelatihan Kewirausahaan Pasar Online"
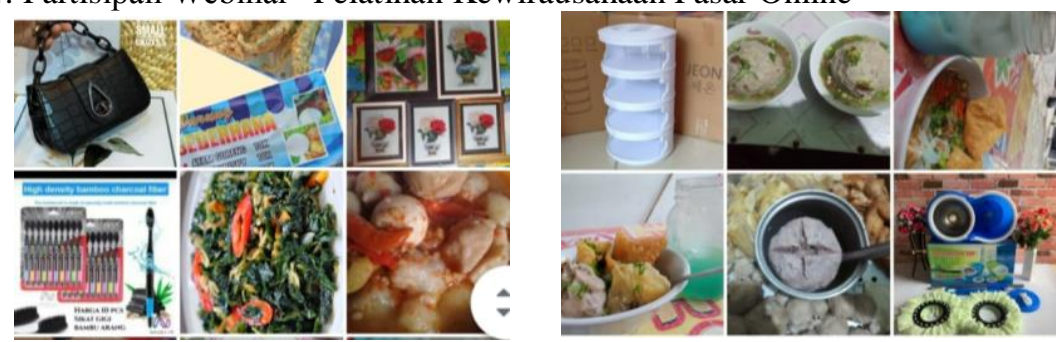

Gambar 5: Produk Pasar Online UMKM Mojolangu

\section{KESIMPULAN}

Kegiatan pengabdian ini mengusung tema "Pelatihan Kewirausahaan Berbasis Teknologi: Pasar Online". Dampak kegiatan ini terhadap mitra adalah adanya peningkatan omset usaha di dalam masa pandemik Covid-19. Diharapkan dengan pelatihan kewirausahaan berbasis teknologi ini, maka akan ada perluasan usaha mitra ke daerah lain di luar Kota Malang dan luar Jawa Timur. Mitra juga mendapat manfaat antara lain kemudahan untuk mengakses situs web dan akun sosial media. Dengan penerapan pasar online, mitra memperoleh nilai tambah dari toko online tersebut, antara lain memiliki daftar pelanggan tetap yang membeli produknya baik konsumen yang berasal dari pasar lokal, nasional maupun pasar internasional. Pelaksanaan kegiatan mampu meningkatkan pengetahuan dan kemampuan mitra dalam penerapan pasar online. Selain itu situs web memberikan kemudahan mitra dalam melakukan kegiatan pemasaran produknya. Mitra akan mendapatkan manfaat dari efisiensi waktu, terutama dalam menjangkau konsumennya di mana pun di masa pandemik ini. Penerapan pasar online dapat membantu meningkatkan omset dan perluasan usaha.

\section{DAFTAR PUSTAKA}

Ayu Puti, E. 2013. Aplikasi Instagram Sebagai Media Komunikasi Pemasaran Online Shop (Studi Deskriptif Kualitatif Aplikasi Instagarm Sebagai Media Komunikasi Pemasaran Online Shop).

Surabaya: FISIP Universitas Pembangunan Nasional "Veteran" Jawa Timur.

Kaplan, Andres. Haenlein, Michael. 2010. User Of The World. Unite! The Challenges and

Opportunities Of Social Media. Business Horizons.

Nafi, Muchamad. 2020. Pengertian UMKM, Kriteria Kekayaan, dan Pemberdayaan di

TengahPandemi.https://katadata.co.id/muchamadnafi/berita/5ebe19afb009d/pengertian-umkm-

kriteria-kekayaan-dan-pemberdayaan-di-tengah-pandemi.

Reimers, V. Chao, C. W. Gorman, S. 2016. Permission Email Marketing and Its Influence on Online Shopping. Asia Pacific Journal of Marketing and Logistics, 28 (2), 308 -322.

Triyaningsih, S. L. 2012. Dampak Online Marketing Melalui Facebook Terhadap Perilaku Konsumtif Masyarakat. Jurnal Ekonomi dan Kewirausahaan, 11(2). 
Yulianto, A. 2015. Kajian Internet Marketing Sebagai Salah Satu Media Pemasaran Industri Perhotelan. Jurnal Khasanah Ilmu, 6 (1), 65-78.

https://www.statista.com/statistics/254456/number-of-internet-users-in-indonesia/

https://ngalam.co/2015/12/30/profil-kecamatan-lowokwaru-malang/ 